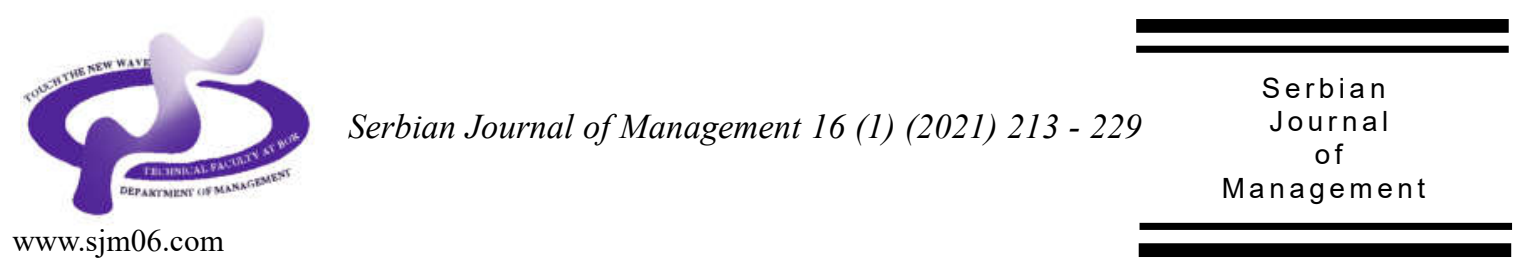

\title{
THE IMPROVEMENT OF COLLABORATIVE NETWORKS TO INCREASE SMALL AND MEDIUM ENTERPRISES (SMES) PERFORMANCE
}

\author{
Mulyana Mulyana* and Wasitowati Wasitowati \\ Department of Management Science, Faculty of Economics, Universitas Islam Sultan \\ Agung ,Semarang, Indonesia
}

(Received 10 December 2019; accepted 26 August 2020)

\begin{abstract}
This study aims to examine the effect of collaborative networks on business performance. This study tries to find a collaborative network format that can improve business performance. The respondents in this study were 295 owners of the fashion sector SMEs in Central Java, Indonesia. Data analysis used the Structural Equation Modeling (SEM) approach. The results showed that collaborative networks (CN) significantly influence innovation capability (IC), competitive advantage (CA), and business performance (BP). Furthermore, the capability of innovation and competitive advantage also significantly influence business performance. Innovation capabilities and competitive advantages can mediate the relationship between collaborative networks and business performance.
\end{abstract}

Keywords: collaborative networks, innovation capabilities, competitive advantage, business performance

\section{INTRODUCTION}

Scientists agree that SMEs have a large role as the basis of a country's economic development especially contributing to economic growth and reducing unemployment (Günay \& Apak, 2014; Mahmud \& Hilmi, 2014). The business environment is changing very dynamically, fashion SMEs need a wide network to facilitate access to information, sharing knowledge and experience. Collaborative networks by fashion SMEs have an important role to be achieved in this research. Collaborative networks can be done through collaboration with suppliers, competitors, customers, governments with the hope of sharing information, knowledge and experience to support company innovation (Zhou \& Li, 2012; Luzzini et al.,

\footnotetext{
*Corresponding author: mulyana@unissula.ac.id
}

DOI: $10.5937 /$ sjm16-24369 
2015; Clauss \& Kesting, 2017). Collaborative networks are also designed as an innovation strategy and are developed to assess the competence of external network partners, namely universities, companies, and government (Varrichio et al., 2012). Effective collaborative networks will create cooperative relationships that are able to expand business opportunities and company growth (Starr \& MacMillan, 1990; Garnsey, 1998).

This study aims to determine the effect of collaborative networks on the capabilities of innovation, competitive advantage, and fashion SMEs performance in Central Java, Indonesia. Central Java was chosen due to the number of fashion SMEs that is very large and the ability to access information is still limited. Also, the development of fashion SMEs requires companions from competent institutions and regulatory support from local and central governments that support SMEs.

According to the author's knowledge, there has not been much research on the relationship between collaborative networks and SMEs performance in Central Java, Indonesia. The author has examined the collaborative networks and entrepreneurial orientation with different objects, that is in the creative industry. This research focus on examining the ability of networking with external parties conducted by leaders or owners of creative industries. The results showed that the average ability of the owner or leaders of the creative industry in building networks with external parties was not optimal because of the limited ability of human resources, the ability to access information, and differences in regulations among local governments (Mulyana and Sutapa, 2016).

Previous research also has found inconsistent results and no one has even found a standard format on the role of collaborative networks as a determinant of business performance. Previous studies have shown that collaborative networks are determinants of business performance (Ramayah et al., 2011), and drivers of trade transactions (Ziemer \& Long, 2009). Likewise, networking built by SMEs with customers, research institutions, supporting institutions can increase company growth (Panda, 2014). Other studies show different results, collaborative networks conducted by SMEs in Australia with research and development institutions, customers, industry, distributors and other collaborations cannot improve financial performance (Wang \& Lee, 2014) and collaborative network size in non-profit organizations is also not able to improve organizational performance (Ofem, 2014).

Central Java, Indonesia, consists of 35 districts/cities with different regulations in developing SMEs so that not all SMEs can adapt quickly to district/city government regulations. Besides, there are also differences in the ease of information access in each region and the limited capabilities of human resources and the current network. Based on the research problem and conceptual model developed, the five hypotheses can be developed and it is expected to be able to explore the role of collaborative networks in improving SMEs performance.

\section{LITERATURE REVIEW}

\subsection{Collaborative Networks}

Collaborative is defined in many ways that describe mutually beneficial cooperation 
(Camarinha-Matos, 2009). Collaborative networks with business partners will make them easier to share knowledge and information to improve innovation capabilities through relationships with clients, suppliers, competitors, and research organizations (Tsai, 2009). Collaborative networks can be developed vertically through clients, suppliers, and competitors and horizontally through research institutions, universities, and government support (Zeng et al., 2010). Collaborative networks as a means to build synergies for the development of organizational innovation for mutual progress (Ziemer et al., 2009; Najib et al., 2014). Collaborative innovation networks are interactions with suppliers, customers, competitors, and research organizations that are designed for new product development (Najafi-Tavani et al., 2018). In this study, collaborative networks are interactions with suppliers, competitors, customers, and the government that is designed to strengthen innovation, competitive advantage, and business performance.

\subsection{Innovation Capability}

Penrose (1959) states that Resources Based View (RBV) regards resources and capabilities as components in the company. Barney (1991) believed that if the valuable, scarce, and difficult to imitate resources are managed properly, it can create a competitive advantage. Capability is a managerial skill to empower company assets to create competitive advantage (Day, 1994). Innovation is a process of thinking that starts from an idea, continue to develop findings and produce new products, processes, and services that can be offered to the market (Thornhill, 2006). Innovation capability can be demonstrated through the ability to try new ideas, find new ways, new operating methods, enter the market with new products to improve company performance (Hult et al., 2004). Innovation capability is needed by organizations to support product innovation so that it has an impact on increasing sales, profits and becoming a competitive force (Battor \& Battor, 2010). Innovation capability is an internal capability that influences an organization in achieving sustainable innovation and adds value to the organization and its stakeholders (Saunila, 2016). Innovation capability can be used to ensure company performance through meeting customer needs so companies need to build satisfying relationships and retain customers (Ngo \& O'Cass, 2012). In this research, innovation capability is the ability to develop creativity and innovation through business networks to produce new products and expand markets.

\subsection{Competitive Advantage}

Barney (1991), Resources Based View (RBV) illustrates that there is a strong relationship between organizational resources and competitive advantage. Companies try to use their resources to create a competitive advantage in the market and have an impact on superior performance. Likewise, superior resources owned by a company will create a competitive advantage in the market (Hunt \& Morgan, 1996). The position of competitive advantage can lead organizations to achieve superior performance through increased market share and profitability (Fahy et al., 2000). Competitive advantage can be created through better service than competitors, lower costs, having the right strategic choices and the potential to improve 
company performance (Kuo et al., 2017). Likewise, competitive advantage developed through price, quality, delivery of goods, interdependence, product innovation, and speed of delivery of products to the market so that it can drive business performance (Wijetunge, 2016). In this study, competitive advantage is the company's ability to meet customer needs and satisfaction and create customer value better than competitors.

\subsection{Business Performance}

Business performance can be achieved through multidimensional indicators of company success, as measured through returns on sales, returns on assets, profitability, market share, sales revenue, labor productivity and employment (Rosli \& Sidek, 2013). Company performance is output that can be measured through Return on assets (ROA), Return on Investment (ROI), Return on Sales (ROS), and overall profitability (Calantone et al., 2002). The measurement of company performance is directed at how much the company controls the market and is oriented towards financial goals so that it can be measured through market share growth, sales growth, profits and return on assets (Hsu, 2012). Business performance is the company's success in finance and marketing measured by return on assets, return on sales, market share growth and sales growth (Dibrell et al., 2014). Business performance is the company's achievements in new product performance, market performance, and financial performance. The performance of a new product is successful when the new product is on purpose, more profitable and successful than competitors. Market performance is achieved through customer satisfaction, customer value, and the fulfillment of customer needs, while financial performance is achieved through return on investment and return on sales (Tzokas et al., 2015). Business performance is the achievement of internal and external work results from all operational activities of the organization, measured through return on assets, sales growth, market share growth, and profit growth (Nuryakin et al., 2018). In this study, business performance is the company's ability to achieve marketing and financial performance goals.

\section{HYPOTHESES DEVELOPMENT}

\subsection{Collaborative Networks and Innovation Capabilities}

Collaborative networks become a means of strengthening innovation capabilities (Ziemer \& Long 2009; De Noni et al., 2018) and are built through four elements; suppliers, clients, competitors, and research organizations (Tsai, 2009). Collaborative networks can be built through external networks, which is cooperation with universities, competitors, and governments able to support the development of innovation (Varrichio et al., 2012; Najib et al., 2014). Collaborative networks can be built vertically through collaboration with clients, suppliers, and competitors while horizontally covering research institutions, universities, and government to strengthen innovation (Zeng et al., 2010). In SMEs, the implementation of informal collaborative networks is more effective than the formal ones by utilizing knowledge and information quickly and flexibly to improve innovation performance (Santoro et al., 2018). Collaborative innovation networks have a strong relationship with new product 
innovations (Najafi-Tavani et al., 2018). Therefore, harmonious collaborative networks with external partners will be shared knowledge, experience, and information sharing so that it creates the spirit to change for the better and has the potential to improve innovation capabilities.

H1: Colaborative networks has a significant effect on innovation capability

\subsection{Collaborative Networks Competitive Advantage}

Competitive advantage can be enhanced by building an external network on an ongoing basis. Organizations that can develop harmonious cooperation strategies with suppliers and customers will be able to create a competitive advantage (Gilaninia et al., 2011). Competitive advantage is one of the keys to long-term business success and will be created if the company can provide higher value than other companies. The development of the right network will make it easy to share company knowledge, skills, and resources so that the right cooperative strategy is needed to be able to create a competitive advantage (Wu et al., 2011). Collaborative networks as a means to share knowledge, skills, and resources that can create a competitive advantage through specialization and cooperation (Kolaković \& Morić Milovanović, 2010). Collaborative networks can create competitive advantage by sharing roles in collaboration so that they will deliver maximum results in the face of environmental pressures (Mezgár et al., 2000). Therefore, the ability to build networks will increase knowledge, skills and cost efficiency in creating new products and services so that it has the potential to create a competitive advantage.
H2: Collaborative networks has a significant effect on competitive advantage

\subsection{Collaborative Networks and Business Performance}

Collaborative awareness is needed to create more harmonious cooperation with business partners (Barnes \& Liao, 2012) and networking developed among leaders, customers and the government can drive business performance improvement (Panda, 2014). Likewise, SMEs that can build networking with the right partners will influence the growth of the company (Širec \& Bradač, 2009), while the customer collaboration developed by SMEs can improve marketing performance (Fidel et al., 2015). Collaborative network orientation has a relationship with business performance (Sorenson et al., 2008). Likewise, the characteristics of the non-individual external business such as economic, political, and social are very influential on the success of SMEs after experiencing a failure (Nikolić et al., 2019). Therefore, good collaborative networks with partners will create information and knowledge sharing. In addition, strong cooperation can encourage sales, profit, and risk-sharing, thereby potentially increasing business performance.

H3: Collaborative networks has a significant effect on business performance

\subsection{Innovation Capability and Business Performance}

The ability of companies to create quality and inexpensive products is needed creativity and innovation and the better the quality of the product, the higher the performance of the organization (Lakhal, 
2009). Innovation carried out by making product changes, production processes, new product designs, and new business development are able to improve business performance (Bayraktar et al, 2016). Likewise, sustainable growth in small and medium-sized companies is largely determined by the ability of innovation ( Mirza \& Ali, 2011). Companies that are proactive to external stimuli will be able to improve innovation capabilities and improve market performance better than those that are only reactive to external stimuli (Ribau et al., 2017). Innovations developed through the introduction of new products, new production processes, and new management systems can improve company performance (Rosli and Sidek, 2013; Naranjo-Valencia et al, 2016; Serna et al, 2016). The development of innovation by trying new ideas and methods, new operating methods, and entering new market targets by offering new products can improve company performance (Calantone et al., 2002). The development of innovation by SMEs through creating new products that are different from competitors, trying new production process methods, and improving management, can drive sales growth, profits and market share (Mulyana \& Sutapa, 2016; Serna et al., 2016; Sulistyo \& Siyamtinah, 2016). The speed of product innovation will allow companies to enter the market faster so that they can increase profits and market share better than competitors (Jovanović et al., 2018). Therefore, innovation capabilities developed through product innovation, process innovation, market innovation, and packaging innovation have the potential to improve business performance.

H4: Innovation capability has a significant effect on business performance

\subsection{Competitive Advantage and Business Performance}

Competitive advantage has a big role in determining business performance. Competitive advantage can be created through superior value for customers, product and service quality, innovation, and organizational effectiveness (Chiou, 2011). Companies that are able to add value to customers are better than competitors and have the capability of innovation will have a competitive advantage (Dustin et al., 2014). The higher the company's ability to create a competitive advantage, it can illustrate the higher company's performance (Naala \& Rosli, 2016). Competitive advantage that is created through better service than competitors, lower costs, and the right choice of strategies has the potential to improve company performance (Kuo et al., 2017). Likewise, competitive advantage developed through price, quality, delivery of goods, interdependence, product innovation, and speed of products delivery to the market can drive business performance, for example increasing annual sales, increasing annual profits, employee growth, market share growth, and growth investment (Wijetunge, 2016). Therefore, competitive advantage created through increasing product quality, lower prices than competitors, creating new products that are different, and building good relationships with customers has the potential to improve business performance.

H5: Competitive advantage has a significant effect on business performance

The hypotheses development that contribute to this paper is shown in Figure 1. 


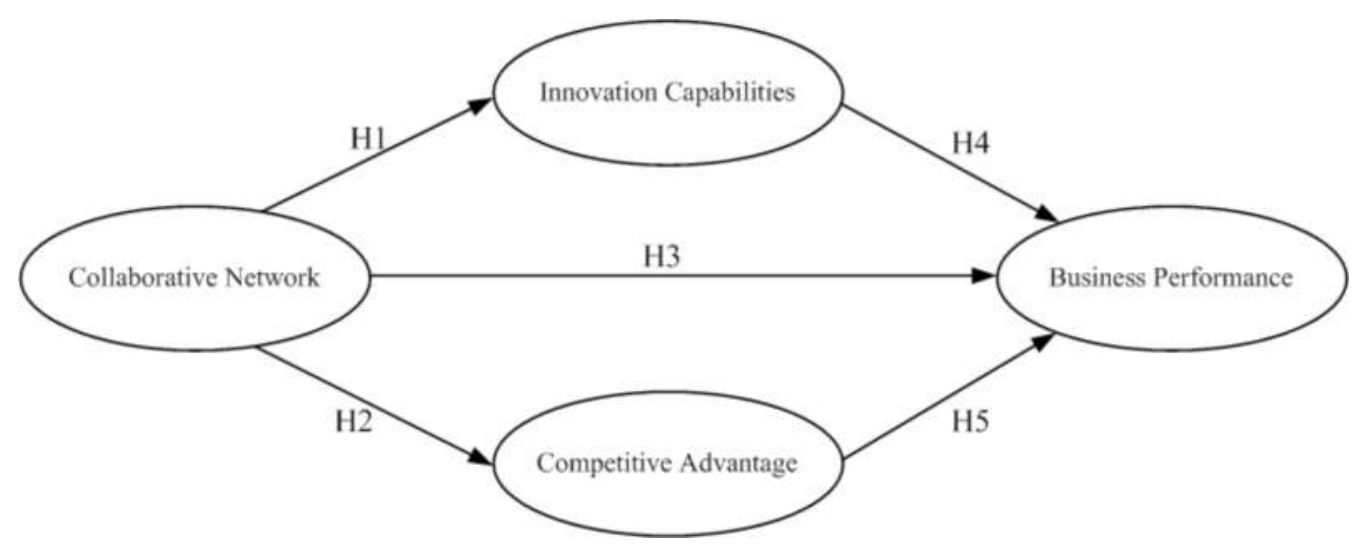

Figure 1: Conceptual framework

\section{RESEARCH METHOD}

\subsection{Data collection and Sample}

The research object is the fashion sector SMEs in Central Java, Indonesia and respondents are the owners or leaders of SMEs who have experience in managing a business for at least 3 years. SME owners or leaders are considered to know collaborative networks, innovation capability, competitive advantage, and business performance. Data is collected by distributing questionnaires and interviews with SME owners or leaders to obtain accurate information. The questionnaire was distributed to 412 respondents and were returned as many as 326 questionnaires, after being selected only 295 questionnaires $(71.6 \%)$ were eligible as respondents. Distribution of respondents consisted of $32.4 \%$ men and $67.6 \%$ women and ages between 24 to 55 years and having experience in managing business on average 3 to 18 years.

\subsection{Measurement}

The construct is measured by using a scale of 1 to 5 , $(1=$ Strongly Disagree and 5 $=$ Strongly Agree). The scale is used to measure the variables of collaborative networks, innovation capability, competitive advantage, and business performance. The measurement of the research construct was adapted from some of the available literature and was modified to suit the research context. Collaborative networks are measured through indicators adapted from (Najib et al., 2014; Najafi-Tavani et al., 2018), which are: collaborative with suppliers, collaborative with customers, collaborative with competitors, collaborative with the government. In addition, innovation capability is measured through indicators adapted from (Lee \& Hsieh, 2010; Najib et al., 2014) which are: market innovation, product innovation, process innovation, and packaging innovation. Competitive advantage is measured through indicators adapted from (Wingwon, 2012; Hosseini et al., 2012) include price/low cost, quality innovation, customer relationship, and difference. Business performance is measured through indicators adapted from (Wingwon, 2012; Nuryakin et al., 2018) include market share growth, sales growth, profit growth, and Return on Assets (ROA). 


\subsection{Data analysis and Measurement models}

The Structural Equation Model (SEM) approach is used to process data and facilitate the testing of research hypotheses.

There are two types of variables that need to be analyzed through SEM, namely latent variables and manifest variables. Latent variables are measured through indicators as a reflection of the construct being developed and manifest variables can be known directly. The results of the evaluation of the fit model are done through several goodnessof-fit indices, such as normal fit index (NFI); comparative index (CFI); Tucker-Lewis Index (TLI); root mean square error of approximation (RMSEA); and the Chisquare statistic.

In Table 1, all indicators have a loading factor $>0.5$, so all indicators are valid. Table 2 shows all constructs are reliable or all indicators of the latent variables measured have internal consistency (Hair et al., 2010). All indicators tested have met internal

Table 1. Confirmatory Factor Analysis test results

\begin{tabular}{|c|c|}
\hline Variable and Indicator & Loading factor \\
\hline \multicolumn{2}{|l|}{ Collaborative Networks } \\
\hline My company has built cooperation with raw material providers & .62 \\
\hline My company has built partnerships with competitors & .66 \\
\hline My company is trying to build cooperation with customers & .59 \\
\hline My company always builds cooperation with local governments & .68 \\
\hline \multicolumn{2}{|l|}{ Innovation Capability } \\
\hline Our company often introduces new packaging & .70 \\
\hline Our company is always looking for new market breakthroughs & .68 \\
\hline Our company is always innovating new products & .70 \\
\hline Our company always tries new production processes & .65 \\
\hline \multicolumn{2}{|l|}{ Competitive Advantage } \\
\hline My company sets prices that are affordable or lower than competitors & .68 \\
\hline My company is always innovating new product quality & .73 \\
\hline My company has built business relationships with customers & 68 \\
\hline My company often creates products that are different from competitors & .64 \\
\hline \multicolumn{2}{|l|}{ Business Performance } \\
\hline Company profits experience growth every year & 61 \\
\hline The company's sales have increased every year & .73 \\
\hline The company's market share has increased every year & .73 \\
\hline Return on Assets (ROA) has increased every year & .61 \\
\hline
\end{tabular}

Table 2. Reliability and AVE Test Results

\begin{tabular}{lcccc}
\hline \multicolumn{1}{c}{$\mathbf{N}=\mathbf{2 9 5}$} & 1 & 2 & 3 & 4 \\
\hline Collaborative Innovation Networks & .73 & & & \\
Innovation Capability & .40 & .78 & & \\
Competitive Advantage & .42 & .47 & .78 & \\
Business Performance & .47 & .35 & .47 & .76 \\
Average Variance Extracted (AVE) & .53 & .63 & .63 & .60 \\
\hline
\end{tabular}


consistency standards, namely reliability values $(\mathrm{CR})>0.6$, and Variance Extracted $(\mathrm{VE})>0.5$. Furthermore, the variables of collaborative networks, innovation capability, competitive advantage, and business performance have AVE $>0.5$ and $\mathrm{CR}>0.7$.

\section{FINDINGS}

There are several criteria that must be met in SEM so that the model is suitable to be used to test the relationship between research variables. Test results on the Goodness-ofFit index are good and fit the recommended criteria of SEM. The value of $\chi^{2}=102.63$ and not significant at $\alpha$ : 0.05, GFI index:
0.95; AGFI: 0.94; TLI: 0.99, meaning that all values meet the recommended SEM, which is $\geq 0.90$. The value of RMSEA: 0.01 $<0.08$ and CMIN / DF 1.03 less than 2.00. Thus, the model is feasible to use to test the relationship between the variables.

Table 3 and Figure 2 show that $\mathrm{CN}$ has a significant effect on IC $(\operatorname{Std} \beta=.40, \mathrm{CR}=$ 4.79 , prob. $<0.05$ ). Furthermore, there was a significant positive effect of CN on CA (Std $\beta=.42, \mathrm{CR}=4.79$, prob. $<0.05), \mathrm{CN}$ on $\mathrm{BP}$ $(\operatorname{Std} \beta=.25, \mathrm{CR}=2.84$, prob. $<0.05)$, and $\mathrm{IC}$ on $\mathrm{BP}(\operatorname{Std} \beta=.34, \mathrm{CR}=4.09$, prob. $<$ $0.05), \mathrm{CA}$ on $\mathrm{BP}(\operatorname{Std} \beta=.19, \mathrm{CR}=2.36$, prob. $<0.05)$. Thus, $\mathrm{H} 1, \mathrm{H} 2, \mathrm{H} 3, \mathrm{H} 4$ and $\mathrm{H} 5$ are accepted. Sobel test is used to test the role of IC as a mediating variable between $\mathrm{CN}$ and BP. Sobel test results $=3.15$; prob.

\section{Table 3. Hypothesis Testing}

\begin{tabular}{lccccc}
\hline Relationship Specifications & Stand. $\beta$ & Unstd. $\beta$ & SE & C. R. & Prob. \\
\hline H1: CN -> IC & .40 & .38 & .08 & 4.79 & .00 \\
H2: CN -> CA & .42 & .36 & .07 & 4.79 & .00 \\
H3: CN-> BP & .25 & .21 & .07 & 2.84 & .00 \\
H4: IC ->BP & .34 & .30 & .07 & 4.09 & .00 \\
H5: CA -> BP & .19 & .18 & .07 & 2.36 & .01 \\
\hline
\end{tabular}

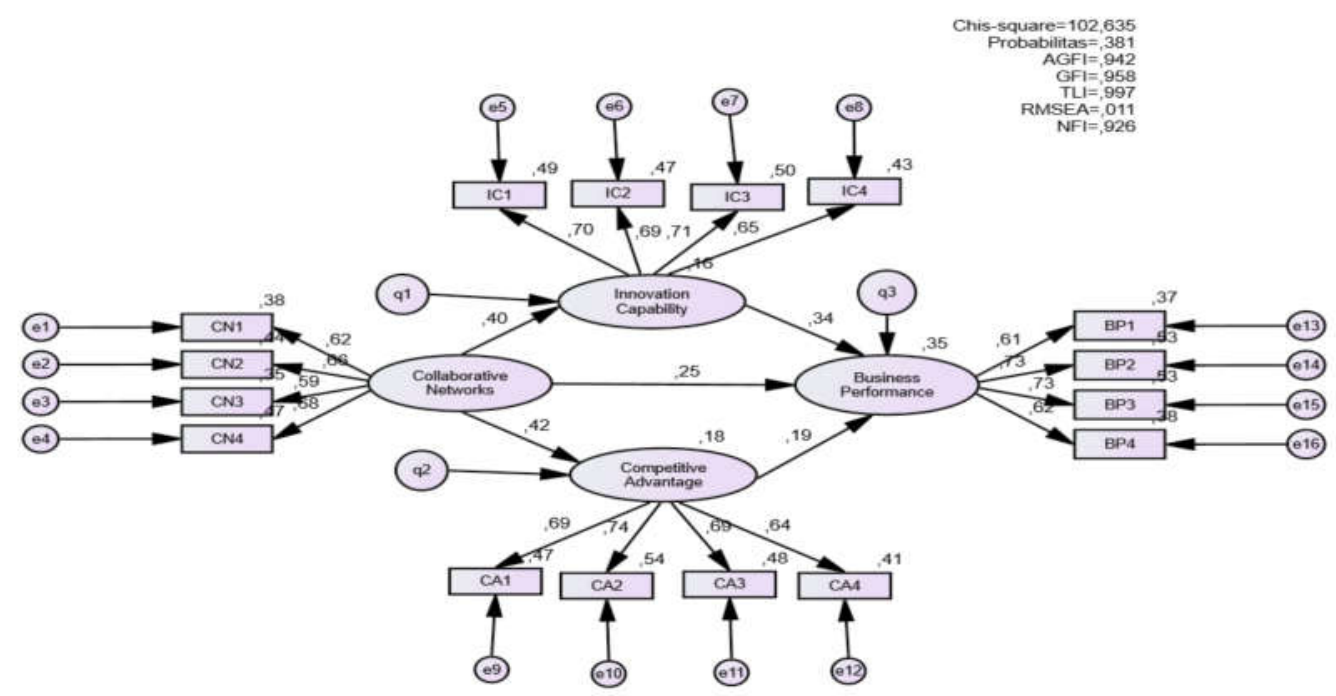

Figure 2. Full structural model 
$0.00<0.05$. Thus, IC mediates the government regulations that support SMEs relationship between $\mathrm{CN}$ and $\mathrm{BP}$. are urgently needed in order to encourage Furthermore, the test of CA as a mediating innovation success. The results of this study variable between $\mathrm{CN}$ and $\mathrm{BP}$ shows the results of the Sobel test $=2.08$ and prob. 0.01 $<0.05$, so it was concluded that CA mediates the relationship between $\mathrm{CN}$ and $\mathrm{BP}$.

\section{DISCUSSION}

Collaborative networks have a big role to play in enhancing the capabilities of innovation. The results of this study support the results of previous studies, that collaborative networks can encourage the development of innovation (Ziemer \& Long 2009; Najib et al., 2014). Likewise, collaborative networks are needed to design an innovation strategy by utilizing external network competencies, both with universities, companies, and government (Varrichio et al., 2012). SMEs fashion has built a network with suppliers of raw materials to maintain the continuity of the availability of raw materials. The style element is very dominant in the fashion industry and changes very quickly according to market needs, so the speed of innovation is needed in order to respond to needs. The availability of raw materials is one of the supports for the success of product innovation and process innovation in meeting customer needs. Networking with customers is needed in order to know the needs and desires of customers so that SMEs can re-arrange their resources in order to provide the best value for customers. Cooperation with competitors is expected to occur in sharing knowledge, sharing market information, and mutually beneficial collaboration so that it can encourage the strengthening of innovation. Likewise, are supported by the findings that building networks with suppliers, clients, competitors, and research organizations is a model of collaborative networks to support the development of innovation (Tsai, 2009; Zeng et al., 2010).

Collaborative networks can create a competitive advantage. The results of this study support the findings of previous studies that the development of business networks will occur sharing knowledge, experience, skills, and resources so as to create competitive advantage through specialization and cooperation ( Kolaković \& Morić Milovanović, 2010). Good cooperation with suppliers of raw materials has an important role to support the smooth production process, efficient management of raw materials, and the creation of efficient production processes so as to create products at affordable prices for customers. A harmonious relationship with the customer is always done by providing new products according to customer expectations, responding to customer complaints quickly so that customer loyalty is maintained. Collaboration with competitors is carried out in order to meet the target market, so competitors are considered partners by carrying out sub-contract production if there is a demand that exceeds production capacity or customer demand that cannot be fulfilled. The role of the government is providing regulatory support, means of promotion, tax relief, coaching, and training to strengthen competitiveness. Strengthening the network of cooperation can encourage the creation of competitive advantage through knowledge sharing both externally and internally (ScottKennel \& Giroud, 2015). 
Collaborative networks can improve business performance. In line with the findings that collaborative networks can improve business performance (Ramayah et al., 2011, Al-Hakim \& Lu, 2017). The ability of fashion SMEs to build partnerships with suppliers can guarantee the availability of raw materials, cost efficiency, and companies can set affordable prices for customers so that it will affect the increase in sales. Likewise, cooperation with competitors is carried out mainly in meeting the surge in unserved demand, by conducting mutually beneficial production subcontracts. SMEs always maintain good relations with their customers, this is very petrified in promotional activities, for example, by word of mouth or through social media groups owned by customers so that it affects the expansion of market share, sales, and profits.

Innovation capability can improve SMEs performance. The findings of this study are in line with the opinion that the capability of innovation can improve company performance (Mulyana \& Sutapa, 2016). Product innovations made by fashion SMEs always follow the developing trend, for example, design, style, style, and color with the aim of providing a variety of products according to customer expectations. Process innovation is carried out by trying new production process methods to produce quality new products according to market trends so as to increase the number of customers and sales. The results of previous empirical studies also stated that the company's performance is strongly influenced by product innovation and process innovation (Mahmood \& Hanafi, 2013). The packaging is also a concern for fashion SMEs, with attractive packaging that will enhance the company's image that the products produced have good quality for customers. Therefore, fashion SMEs are always looking for new market breakthroughs by offering quality products and attractive packaging in order to increase sales and corporate profits.

Competitive advantage has an important role to improve business performance. Russell ans Millar (2014) stated that business performance can improve if the company has a competitive advantage. Likewise, improving business performance can be achieved if the company is able to develop appropriate competitive strategies (Abdul Halim et al., 2011). Fashion SMEs always try to provide quality products according to market trends and try to provide new products that are different from competitors to retain customers. New products that are unique as the characteristics of certain regions often become excellent products that are much favored by local customers, so that cooperation with communities, government, and nongovernment organizations becomes a potential market. Likewise, building longterm relationships with customers continues, with the hope that loyal customers are willing to provide input in the interests of both parties. Efforts to retain loyal customers also continue to be done by providing a variety of products, discounts, bonuses, and respond quickly for customer complaints. Fashion SMEs also provides a variety of products at varying and affordable prices according to the ability of sales customers and corporate profits.

Innovation capabilities are able to mediate the relationship between collaborative networks and business performance. Collaborative networks developed by fashion SMEs with external parties, such as customers, suppliers, 
competitors, and the government have created sharing knowledge, experience, and information that encourage to strengthen innovation and have an impact on business performance. Competitive advantage can mediate the relationship between collaborative networks and business performance. The ability of fashion SMEs to build good relationships with customers, suppliers, competitors, and the government will create advantage so that it can create quality products and affordable prices for customers. Furthermore, maintaining good relations with customers should continue, so that it impacts on improving business performance.

\section{CONCLUSION AND IMPLICTIONS}

Collaborative networks can be developed by building harmonious cooperation with suppliers, competitors, customers and the government. Networking with suppliers can maintain the availability of raw materials so that the production process is not interrupted and create cost-efficient procurement of raw materials. Networking with competitors can build mutually beneficial cooperation in order to meet market demand that exceeds production capacity between them by conducting sub-contract production and market sharing agreements. Maintaining good relations with customers can know the wants and needs of customers and be able to respond quickly to customer needs. Government regulations that support fashion SMEs are very much needed so that fashion SMEs can develop and be able to compete in the market. Collaborative networks with appropriate and mutually beneficial partners will encourage knowledge and information sharing to strengthen product innovation, process innovation, market innovation and packaging innovation, so that it will have an impact on improving business performance. Likewise, a good implementation of collaborative networks will help fashion SMEs in providing a variety of new products with the best quality for customers. The availability of unique products according to the characteristics of certain regions, affordable prices and in accordance with market trends will be the customer's expectations. These advantages will encourage increased business performance.

The managerial implications of this study are that to improve the performance of fashion SMEs, strong collaborative networks are needed with external partners. Fashion SMEs must build harmonious cooperation with suppliers, competitors, customers and the government to create knowledge, experience, market information sharing so that innovation and competitive advantage occur. Fast-changing fashion trends require the speed of innovation in order to be able to provide new products according to customer needs, which then it has an impact on business performance. The results of this study are expected to strengthen the development of knowledge, especially in the field of marketing management.

The limitations of this study are; (a) this study does not separate small and mediumsized companies in its analysis, while the ability to build collaborative networks between small and medium-sized companies varies. (b) this study only takes the object of fashion SMEs so that the results cannot be generalized to all SMEs that have many types. (c) researchers have not discussed the role of network capacity as an important element for determining network success. Therefore, future research can be developed 
with broader objects by adding network capacity with its main focus on each category of small and medium-sized companies so that this will provide more comprehensive results.

\section{References}

Abdul Halim, M.A.S., Muda, S., \& Mohd Amin, W.A.A.W. (2011). The Measurement of Entrepreneurial Personality and Business Performance in Terengganu Creative Industry. International Journal of Business and Management, 6 (6), 183-193.

Al-Hakim, L., \& Lu, W. (2017). The role of collaboration and technology diffusion on business performance. International Journal of Productivity and Performance Management, 66 (1), 22-50.

Barnes, J., \& Liao, Y. (2012). The effect of individual, network, and collaborative competencies on the supply chain management system. International Journal of Production Economics, 140 (2), 888-899.

Barney, J. (1991). Firm Resources and Sustained Competitive Advantage. Journal of Management, 17 (1), 99-120.

Battor, M., \& Battor, M. (2010). The impact of customer relationship management capability on innovation and performance advantages: Testing a mediated model. Journal of Marketing Management, 26 (910), 842-857.

Bayraktar, C.A., Hancerliogullari, G., Cetinguc, B., \& Calisir, F. (2016). Competitive strategies, innovation, and firm performance: an empirical study in a developing economy environment, Technology Analysis \& Strategic Management, 29 (1), 38-52.

Calantone, R.J., Cavusgil, S.T., \& Zhao, Y. (2002). Learning orientation, firm innovation capability, and firm performance. Industrial Marketing Management, 31 (6), 515-524.

Camarinha-Matos, L.M. (2009). Collaborative Networked Organizations: Status and Trends in Manufacturing. Annual Reviews in Control, 33 (2), 199-208.

Chiou, C.-H. (2011). Dynamic capabilities, collaborative network and business model: An empirical analysis of Taiwan HTC Corporation. African Journal of Business Management, 5 (2), 294-305.

Clauss, T., \& Kesting, T. (2017). How businesses should govern knowledgeintensive collaborations with universities: An empirical investigation of university professors. Industrial Marketing Management, 62, 185-198.

Day, G.S. (1994). The Capabilities of Market-Driven Organizations. Journal of Marketing, 58 (4), 37-52.

De Noni, I., Orsi, L., \& Belussi, F. (2018). The role of collaborative networks in supporting the innovation performances of lagging-behind European regions. Research Policy, 47 (1), 1-13.

Dibrell, C., Craig, J.B., \& Neubaum, D.O. (2014). Linking the formal strategic planning process, planning flexibility, and innovativeness to firm performance. Journal of Business Research, 67 (9), 2000-2007.

Dustin, G., Bharat, M., \& Jitendra, M. (2014). Competitive Advantage and Motivating Innovation. Advances In Management, 7 (1), 1-8.

Fahy, J., Hooley, G., Cox, T., Beracs, J., Fonfara, K., \& Snoj, B. (2000). The development and impact of marketing capabilities in central Europe. Journal of International Business Studies, 31 (1), 6381.

Fidel, P., Schlesinger, W., \& Cervera, A. (2015). Collaborating to innovate: Effects on 


\title{
УНАПРЕЪЕЊЕ КОЛАБОРАТИВНИХ МРЕЖА ЗА ПОВЕһАЊЕ УЧИНКА МАЛИХ И СРЕДЫИХ ПРЕДУЗЕһА (МСП)
}

\author{
Mulyana Mulyana, Wasitowati Wasitowati
}

Извод

Циљ ове студије је да испита учинак колаборативних мрежа на пословне перформансе. Ова студија покушава да пронађе формат колаборативне мреже који може побољшати пословне перформансе. Испитаници у овој студији су 295 власника МСП из модног сектора у Централној Јави, Индонезија.За анализу података коришћен је приступ структурног моделовања једначина (енг. Structural Equation Modeling- SEM). Резултати су показали да колаборативне мреже (енг. collaborative networks - CN) значајно утичу на иновациону способност (енг. innovation capability - IC), конкурентску предност (енг. competitive advantage - CA) и пословне перформансе (енг. business performance - ВР). Штавише, иновациона способност и конкурентска предност такође значајно утичу на пословне перформансе. Иновативне могућности и конкурентске предности могу посредовати у односу између колаборативних мрежа и пословних перформанси.

Кључне речи: колаборативне мреже, иновационе способности, конкурентска предност, пословни учинак

customer knowledge management and performance. Journal of Business Research, 68 (7), 1426-1428.

Garnsey, E. (1998). A Theory of the Early Growth of the Firm. Industrial and Corporate Change, 7 (3), 523-556.

Gilaninia, S, .Chirani, E., Ramezani, E., \& Mousavian, S.J. (2011). The Impact of Supply Chain Management Practices on Competitive Advantage. Interdisciplinary Journal of Contemporary Research in Business, 3 (6), 577-587.

Günay, G.Y., \& Apak, S. (2014). Comparison of Public and Non-public SMEs' Corporate Governance Strategies in Turkey. Procedia - Social and Behavioral Sciences, 150, 162-171.

Hair, J.F., Anderson, R.E., Tatham, R.L. \& Black, W.C. (2010). Multivariate Data Analysis. Prentice Hall. New Jersy.

Hosseini, S.M., Azizi, S., \& Sheikhi, N.
(2012). An Investigation on the Effect of Supply Chain Integration on Competitive Capability: An Empirical Analysis of Iranian Food Industry. International Journal of Business and Management, 7 (5), 73-91.

Hsu, S. (2012). Effects of Competitive Strategy, Knowledge Management and EBusiness Adoption on Performance. Journal of Human Resource and Adult Learning. 8 (2), 42-49.

Hult, G.T.M., Hurley, R F., \& Knight, G A. (2004). Innovativeness: Its antecedents and impact on business performance. Industrial Marketing Management, 33 (5), 429-438.

Hunt, S.D., \& Morgan, R.M. (1996). The Resource-Advantage Theory of Competition: Dynamics, Path Dependencies, and Evolutionary Dimensions. Journal of Marketing, 60 (4), 107-114. 
Jovanović, I., Arsić, M., \& Nikolić, D. (2018). Entrepreneurial personality traits and smes profitability in transition economy. Serbian Journal of Management. 13 (1), 89104

Kolaković, M. \& Morić Milovanović, B. (2010). Strategic Networking As a Driver of Competitiveness of Croatian Small and Medium Enterprises. In An Enterprise Odyssey. International Conference Proceedings . University of Zagreb, Faculty of Economics and Business, Croatia. 12131224.

Kuo, S., Lin, P., \& Lu, C. (2017). The effects of dynamic capabilities, service capabilities , competitive advantage, and organizational performance in container shipping. Transportation Research Part A: Policy and Practice, 95, 356-371.

Lakhal, L. (2009). Impact of quality on competitive advantage and organizational performance. Journal of the Operational Research Society, 60 (5), 637-645.

Lee, J.-S., \& Hsieh, C.-J. (2010). A Research In Relating Entrepreneurship, Marketing Capability, Innovative Capability And Sustained Competitive Advantage. Journal of Business \& Economics Research, 8(9), 109-119.

Luzzini, D., Amann, M., Caniato, F., Essig, M., \& Ronchi, S. (2015). The path of innovation: Purchasing and supplier involvement into new product development. Industrial Marketing Management, 47, 109120.

Mahmood, R., \& Hanafi, N. (2013). Entrepreneurial Orientation and Business Performance of Women-Owned Small and Medium Enterprises in Malaysia: Competitive Advantage as a Mediator. International Journal of Business and Social Science Business, 4 (1), 82-91.

Mahmud, N., \& Hilmi, M.F. (2014).
TQM and Malaysian SMEs Performance: The Mediating Roles of Organization Learning. Procedia - Social and Behavioral Sciences, 130, 216-225.

Mezgár, I., Kovács, G.L., \& Paganelli, P. (2000). Co-operative production planning for small- and medium-sized enterprises. International Journal of Production Economics, 64 (1-3), 37-48.

Mirza W.A., \& Ali, B. (2011). The dilemma of Knowledge Management, innovation and entrepreneurship in SME's : an empirical study. Interdisciplinary Journal of Contemporary Research in Business, 3 (2), 1112-1128.

Mulyana, M., \& Sutapa, S. (2016). The Impact of Entrepreneurial Orientation and Collaborative Networks on Creative Industries Performance. Jurnal Dinamika Manajemen, 7 (2), 166-181.

Naala, M.I. \& Mahmood, R. (2016). Mediating Role of Competitive advantage on the Relationship Between Entrepreneurial Orientation and the Performance of Small. International Business Management, 10 (12), 2444-2452.

Najafi-Tavani, S., Najafi-Tavani, Z., Naudé, P., Oghazi, P., \& Zeynaloo, E. (2018). How collaborative innovation networks affect new product performance: Product innovation capability, process innovation capability, and absorptive capacity. Industrial Marketing Management, 73, 193-205.

Najib, M., Dewi, F.R., \& Widyastuti, H. (2014). Collaborative Networks as a Source of Innovation and Sustainable Competitiveness for Small and Medium Food Processing Enterprises in Indonesia. International Journal of Business and Management, 9 (9), 147-161.

Naranjo-Valencia, J.C., JiménezJiménez, D., \& Sanz-Valle, R. (2016). 
Studying the links between organizational culture, innovation, and performance in Spanish companies. Revista Latinoamericana de Psicologia, 48 (1), 3041.

Ngo, L.V., \& O'Cass, A.. (2012). In Search of Innovation and Customer-related Performance Superiority: The Role of Market Orientation, Marketing Capability, and Innovation Capability Interactions. Journal Poduction Innovation Management, 29 (5), 861-877.

Nikolić, N., Jovanović, I., Nikolić, D., Mihajlović, I., \& Schulte, P. (2019). Investigation of the Factors Influencing SME Failure as a Function of Its Prevention and Fast Recovery after Failure. Entrepreneurship Research Journal. 9 (3), 121.

Nuryakin, Wiet Aryanto, V. D., \& Setiawan, M.B. (2018). Mediating effect of value creation in the relationship between relational capabilities on business performance. Contaduría y Administración, 63 (1), 1-21.

Ofem, B. (2014). Entrepreneurial Orientation, Collaborative Networks, and Non Profit Performance (Doctoral Dissertation). Retrieved from https://uknowledge.uky.edu/cgi/viewcontent. cgi? article $=1004 \&$ context=busadmin_etds

Panda, D.K. (2014). Managerial Network Impacts Firm Performance. Performance Improvement Quarterly, 27 (1), 5-32.

Penrose, E. (1959). The Theory of the Growth of the Firm. Business and Economic, Oxford University Press.

Ramayah, T., Lee, J.W.C., \& In, J.B.C. (2011). Network collaboration and performance in the tourism sector. Service Business, 5 (4), 411-428.

Ribau, C.P., Moreira, A.C., \& Raposo, M. (2017). SMEs Innovation Capabiliies and export Performance: an Entrepreneurial Orientation View. Journal of Business Economics and Management, 18 (5), 920934.

Rosli, M.M., \& Sidek, S. (2013). The Impact of Innovation on the Performance of Small and Medium Manufacturing Enterprises: Evidence from Malaysia. Journal of Innovation Management in Small \& Medium Enterprise, 2013, 885666.

Russell, S.N., \& Millar, H.H. (2014). Exploring the Relationships among Sustainable Manufacturing Practices, Business Performance and Competitive Advantage : Perspectives from a Developing Economy. Journal of Management and Sustainability, 4 (3), 37-54.

Santoro, G., Bresciani, S., \& Papa, A. (2018). Technovation Collaborative modes with Cultural and Creative Industries and innovation performance: The moderating role of heterogeneous sources of knowledge and absorptive capacity. Technovation, 9293, 102040.

Saunila, M. (2016). Performance measurement approach for innovation capability in SMEs. International Journal of Productivity and Performance Management, 65 (2), 162-167.

Scott-Kennel, J., \& Giroud, A. (2015). MNEs and FSAs: Network knowledge, strategic orientation and performance. Journal of World Business, 50 (1), 94-107.

Serna, M.D., Martínez, J.E., \& Martínez, J. (2016). The Impact of Learning Orientation on Innovation and Performance in SME'S in México. International Review of Management and Business Research, 5 (1), 48-65.

Starr, J.A., \& MacMillan, I.C. (1990). Resource Cooptation Via Social Contracting: Resource Acquisition Strategies for New Ventures. Strategic 
Management Journal, 11(special issue), 7992.

Širec, K., \& Bradač, B. (2009). How does Networking Impact the SMEs Growth. Organizacija, 42 (2), 59-66.

Sorenson, R.L., Folker, C.A., \& Brigham, K.H. (2008). The Collaborative Network Orientation: Achieving Business Success through Collaborative Relationships. Etrepreneurship Theory and Practice, 32(4), 615-634.

Sulistyo, H., \& Siyamtinah. (2016). Innovation capability of SMEs through entrepreneurship, marketing capability, relational capital and empowerment. Asia Pacific Management Review, 21 (4), 196203.

Thornhill, S. (2006). Knowledge, innovation and firm performance in highand low-technology regimes. Journal of Business Venturing, 21 (5), 687-703.

Tsai, K. (2009). Collaborative networks and product innovation performance: Toward a contingency perspective. Research Policy, 38 (5), 765-778.

Tzokas, N., Kim, Y.A., Akbar, H., \& AlDajani, H. (2015). Absorptive capacity and performance: The role of customer relationship and technological capabilities in high-tech SMEs. Industrial Marketing Management, 47, 134-142.

Varrichio, P., Diogenes, D., Jorge, A., \& Garnica, L. (2012). Collaborative Networks and Sustainable Business: A Case Study in the Brazilian System of Innovation. Procedia - Social and Behavioral Sciences, 52, 90-99.

Wang, N., \& Lee, V. (2014). Collaborative networks and firm performance: Moderating role of information system integration. Proceedings of the 25th Australasian Conference on Information Systems,. Auckland, New Zealand.
Wijetunge, W.A.D.S. (2016). Service Quality , Competitive Advantage and Business Performance in Service Providing SMEs in Sri Lanka. International Journal of Scientific and Research Publications, 6 (7), 720-728.

Wingwon, B. (2012). Effects of Entrepreneurship, Organization Capability, Strategic Decision Making and Innovation toward the Competitive Advantage of SMEs Enterprises. Journal of Management and Sustainability, 2 (1), 137-151.

Wu, H., Lin, Y., Chien, F., \& Hung, Y. (2011). A Study on the Relationship Among Supplier Capability , Partnership and Competitive Advantage in Taiwan's Semiconductor Industry. International Journal of Electronic Business Management, 9, 122-138.

Zeng, S.X., Xie, X.M., \& Tam, C.M. (2010). Relationship between cooperation networks and innovation performance of SMEs. Technovation, 30 (3), 181-194.

Zhou, K.Z. \& Li, C.B. (2012). How Knowledge Effects Radical innovation: Knowledge Base, Market Knowledge Acquisition and Internal Knowledge Sharing. Strategic Management Journal, 33 (9), 1090-1102.

Ziemer, N., \& Long, S. (2009). Collaborative Networks as Innovation Accelerators. Proceedings of the 2009 Industrial Engineering Research Conference, Miami. 391-397. 